\title{
5 \\ Agencia Benedictina: Burgos, Belgium and the Kimberley
}

Steadily, over a dozen years, women came to New Norcia to join the Benedictine sisters, travelling alone or in twos and threes among the parties of aspiring monks that left Spain with the abbot. By the early 1930s the community of women missionaries had grown to 14 . As this chapter will show, more members enabled the abbot to send his 'oblate sisters' to open the long-awaited convent at Drysdale River in the Kimberley. In turn, the first branch house in the Kimberley reinforced the need for equally long-awaited formal structures, finally pursued in the mid-1930s through Benedictine networks in Belgium. Teresa Roca and Abbot Catalan had hoped new recruits would come from Barcelona. Certainly, their network of friends close to the international port gave them invaluable practical support as young missionaries prepared to leave Spain, but the heart of the effort was the inland city of Burgos. The medieval capital of Castile and its surrounding farming villages proved to be the hub of an informal Agencia Benedictina in these years.

Although the community's hopes were fixed on Spain, the first new arrivals came from Sydney. One, who was briefly known as Mechtilde, enquired about joining in June 1919 and evidently arrived in New Norcia only to be 'headed for the Good Shepherd Sisters in the suburbs' ${ }^{1}$ on 7 October 1920 for reasons the Chronicle does not explain. The other, Nellie Banks,

1 'Chronicle of the Benedictine Community of New Norcia' (hereafter Chronicle), 7 October 1920, New Norcia Archives (NNA). See also Catalan to [Mechtilde], 10 June 1919, NNA 01421/95. 
telegraphed that she was on her way a week later. She was a widow, aged 42, from Drummoyne in Sydney's inner west, born in Redfern. ${ }^{2}$ There was no mention of the mission itself in her correspondence with Fr Rios, the monastery's prior, only the hope she had held for some nine years, 'to live and work for my God in the best manner He has chosen for me'. ${ }^{3}$ Evidently warned about the rural focus of the community, she declared herself ready: 'I might mention I have never done heavy work in my life, but am afraid of nothing. ${ }^{4}$

Nellie arrived in mid-October and everyone at New Norcia was keen to see whether she would 'persevere' as an Anglo-Australian in the community. ${ }^{5}$ When she made her formal commitment as an oblate on the evening of 10 March 1921 the Chronicle lapsed into English to record her new name: Sister Mary Gertrude. The diary noted:

This Lady has been in the Orphanage for our native girls since 16 October last year. She is happy with this kind of life, and the other Sisters are satisfied with her comportment. At the end of the ceremony [Abbot Catalan] preached on the monastic state, congratulating her on her good resolutions and commending them to perseverance. ${ }^{6}$

Among the community of sisters and monks assembled in the church to witness Gertrude's public commitment at St Benedict's altar were two young women who had been at the mission for just three weeks. They were the first of 11 from Burgos who came between 1921 and 1933 to spend the rest of their lives as Benedictine women.

\section{Burgos and missionary tradition}

The first two Spanish postulants, and all the sisters bar one who came in the years before the Spanish Civil War, were village girls from scattered farming settlements west of Burgos; their average age was 19 . We can piece together a roll-call of their arrivals. Isobel Pampliega from the small village of Cañizar de los Ajos was 18 and Perpetua Perez Santamaria from the neighbouring

2 Copy of baptismal certificate, NNA 01365; 'Some History of Redfern', Creative Spirits, www. creativespirits.info/australia/new-south-wales/sydney/redfern; accessed 12 January 2008.

3 Ellen Banks to Fr Rios, 10 February 1920, NNA 01365.

4 Banks to Rios, 10 February 1920.

5 Chronicle, 16 October 1920.

6 Chronicle, 10 March 1921. 
village of Palacios de Benaber was 21 when they sailed into Fremantle with the abbot and 11 young men for the monastery on the Osterley from London on 17 February 1921. ${ }^{7}$ They made their commitment on 25 May 1921 at the same public altar in New Norcias church, taking the names Sister Felicitas and Sister Margarita (quickly known mostly as Margaret). In 1925 Erestina Gozalo and Conceptión Martinez, both teenagers from Cavia, came on the Mooltan to become Sister Benita and Sister Escolastica. Three more young women left villages near Burgos in 1928 to make their way by train to Barcelona and then Marseilles, sailing from there on the Comorin: Benilde Ruiz Bebere from Tapia de Villadiego was 19 years old when she became Sister Hildegard; 17-year-old Martina Cidad Simón from Sasamón became Sister Maria; and Carmen de la Fuente, aged 16, also from Tapia, became Sister Matilde. Aurora Marcos, who became Sister Ludivina, was born in the same year as Sister Margaret Perez and also came from Palacios de Benaber, ${ }^{8}$ but she arrived a decade later, in April 1931, and so she was 31 when she joined the community. Ludivina came on the Ormonde with Trinidad Lopez, who was from the same village and who briefly took the name Sr Edita but did not continue with the community. ${ }^{9}$ Felisa Ruiz de la Barga, who arrived in October 1933, was also older than usual: the future Sister Magdelena, from Cavia where her father was a miller, was 26. Her companions on the Otranto, however, were among the youngest. Andrea Pardo Lopez from the hamlet of Villorejo became Sister Francisca at 16, and Pilar Catalan was just 15 when she became Sister Placida. Pilar, daughter of Abbot Catalan's cousin and from the neighbouring province of Navarra, not Burgos, was the twelfth and last recruit before the Spanish Civil War. She arrived at Corella's railway station in pigtails and a child's short skirt but suddenly understood the journey differently when she met the others, 'so grown up' in skirts to their ankles and swept-up hair. ${ }^{10}$

Each of these young women had a personal account of their decision to join a Benedictine mission in Australia, a drama or romance, a story of faith, family tradition, pragmatism, intuition or decision. The personal stories were bound together by a common rural heritage in settlements no more than 30 kilometres apart and threaded into a whole by referrals that flowed to New Norcia's abbot as he travelled through parishes and convents in the province.

7 Incoming passenger list, Osterley, National Archives of Australia, NAA K269 (Barcode 30151233). See also Chronicle, 15 November 1920.

8 Sr Lorenza Diez to Abbot Catalan, 28 August 1948, NNA 01442-01456.

9 Maria Gratia Balagot, Visitación Cidad and Teresa González, email communication, 13 July 2014.

10 Pilar Catalan in conversation, Madrid, September 2010. 


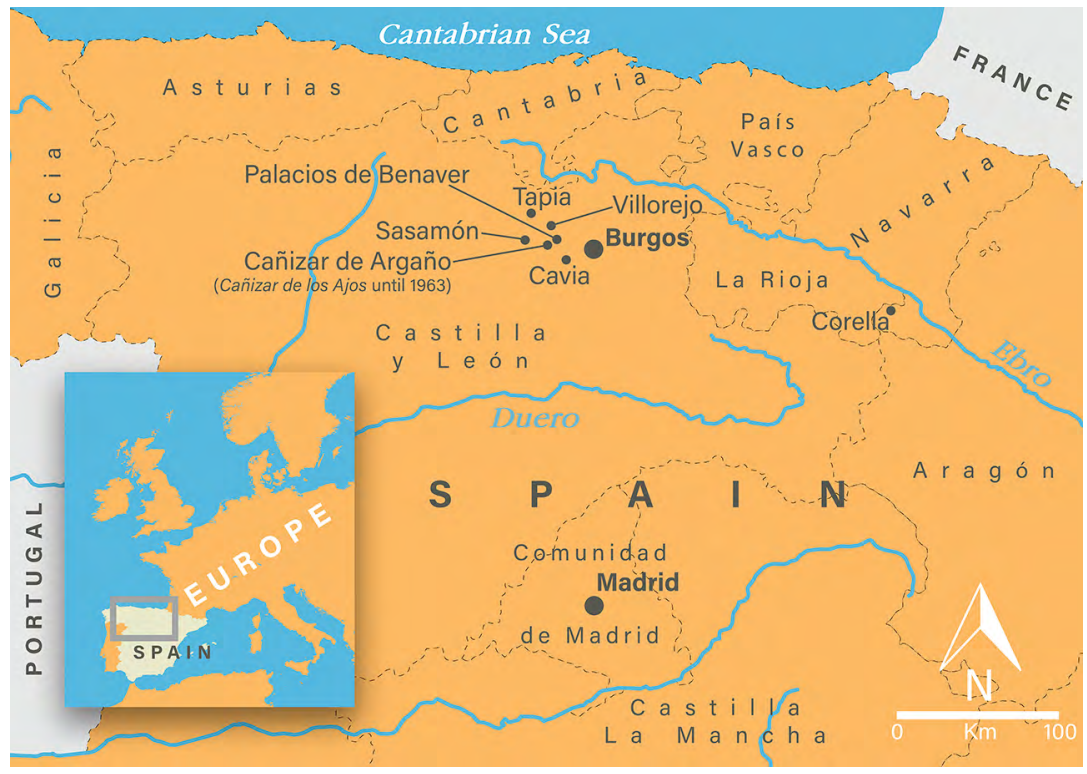

Figure 5.1: Home villages of the Benedictine sisters who arrived at New Norcia, 1921-33 (Cañizar de los Ajos, Cavia, Corella, Palacios de Benaver, Sasamón, Tapia de Villadiego and Villorejo).

Source: Map by Alejandro Polanco Masa.

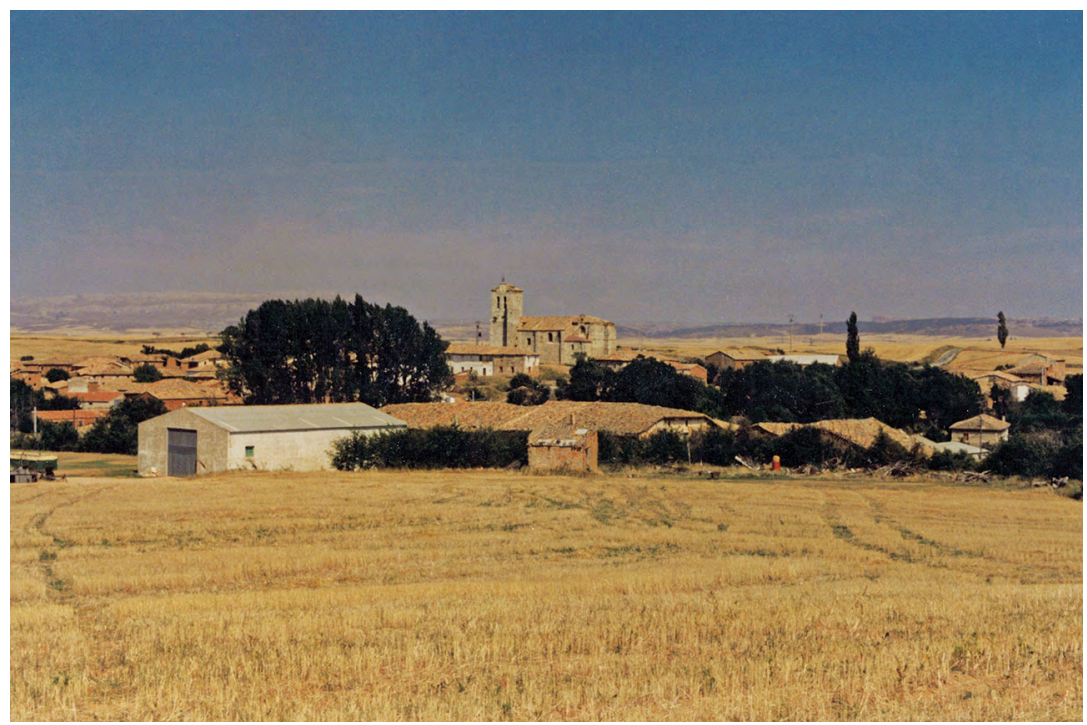

Figure 5.2: The village of Tapia de Villadiego, Burgos.

Source: Archives of the Benedictine Missionary Sisters of Tutzing (ABTM). 
Two communities of contemplative women in Burgos in particular were fundamental to the foundation of the community of missionary women at New Norcia. Both the Benedictine nuns at the monastery of San Salvador in the village of Palacios de Benaver and the Cistercian nuns at the Abbey of Santa Maria Real at Las Huelgas in the township of Burgos itself connected young women from their networks to New Norcia. The communities of Benedictine women at Estrella and Lumbier also played a role in raising awareness of New Norcia. At one level, it was a simple and obvious move on the part of Abbot Catalan to appeal to these nuns: the mission had shimmered on the horizon of Catholic life in Burgos since at least 1883 when Rosendo Salvado had forged a link with Fr Isidoro de Lope Moral. ${ }^{11}$

Fr Isidoro, the parish priest of Barbadillo del Mercado, a small wool-market town near the Benedictine monks at Silos, had been Salvado's agent and the heart of a network that sent brothers and priests to New Norcia in the late nineteenth century. Such a network could certainly locate potential missionary women too. Fr Isidoro had also become chaplain to the abbey at Las Huelgas in 1899 while he was still writing to Salvado. ${ }^{12}$ Certainly his recruiting for the missions was well within living memory in 1915 when Perpetua Perez, the future Sr Margaret, connected with the Cistercian nuns to begin five years with them as a domestic worker. ${ }^{13}$

The networks of friendship and family that brought young missionaries to New Norcia are also evident in the sisters' early community. For example, Felisa Ruiz kept in touch with her friend Escolastica Martinez after Escolastica left Cavia in 1925. In 1931, at the last minute, Felisa backed out of the group Abbot Catalan had gathered. In 1933, she heard through Escolastica's mother that the abbot was recruiting again and wrote to him several times, persuading him that her vocation was now solid. ${ }^{14}$ Families were reluctant to see two daughters go so far, but at various points the Martinez, Pardo and Cidad families were each expecting another sister

11 Fr David Barry, email correspondence to the author, 3 August 2002, 26 August 2002.

12 Teresa De Castro, 'New Norcia's Golden Decade: Rosendo Salvado's Correspondence in the Last Years of the 19th Century (1891-1900)', New Norcia Studies 14 (2006): 64-107.

13 Obituary of Sr Margarita Perez Santamaria, Archives of the Benedictine Missionary Sisters of Tutzing, Carabanchel, Madrid.

14 Catalan to Escolastica Martinez, 24 July 1933, NNA 01434/190. See also Lauren Mosso, "Your Very Affectionate Father in the Lord": The Letters of Abbot Anselmo Catalan during His Visit to Spain, July-August 1933', New Norcia Studies 19 (2011): 53-62. 
to join their daughters Escolastica, Francisca and Maria. ${ }^{15}$ By 1952 three of Hildegard's nieces were professed at New Norcia. ${ }^{16}$ Brothers and male cousins were also encouraged, including in this generation Augustine Gonzalo, Adalbert Perez, Abundio Pardo and Emiliano de la Fuente. More often than not in this chain of migration the men followed their sisters, and the women let it be known they were praying for more vocations from home.

The choices to come to New Norcia were all particular. Some women were propelled into the mission by limited opportunity and the economic hardship of large families; others were drawn by the promise of purposeful service, healthy living or the conviction that God willed this life for them. Abbot Catalan's journeys to 'meet the girls' (encontrando las chicas) are remembered as a significant missionary effort in Benedictine houses in Burgos today, ${ }^{17}$ along with the half-joking sense he evoked among young women with sisters or friends in Australia that 'I would be next'. ${ }^{18}$ Joining the mission was both high drama and yet predictable enough.

In contrast to the attention given to the education and training of young men who came to New Norcia, Abbot Catalan assumed the young women needed no formal preparation for the mission. While future lay brothers trained as shoemakers, bookbinders and carpenters and in gilding and motor mechanics, and while future priests as well as brothers came after some time in formation at a European monastery or even at the archabbey of St Vincent in Pennsylvania for the foundation in the English language it would provide, ${ }^{19}$ the sisters came straight from the villages. Like most Spanish women at this time they had had a rudimentary primary education that equipped them best for the work of a household as 'members of the family' ${ }^{20}$ Literacy among Spanish women through the 1930s ran at about 68 per cent. ${ }^{21}$ All the recruits for New Norcia could read and write, but a few struggled, and there was no priority given to scholarly types.

15 For example, Catalan to Cipriano Martinez (brother of Escolastica), 23 February 1928, NNA 01429/21; Catalan to chaplain at Monastery of San Salvador, Palacios de Beneber, 4 June 1948, regarding Vicenta, NNA 01452/69; Catalan to Maria Nieves Rojo (Cavia), 21 July 1931, NNA 01432/66; Catalan to Melquiades Pampliega, 17 October 1931, NNA 01432/114.

$16 \mathrm{Sr}$ Visitación Cidad, Sr Agnes Ruiz and Sr Matilda Arroyo.

17 Sr Catalina, in conversation, Monastery of San Salvador, Palacios de Beneber, September 2013.

18 Sr Josefina Diez in conversation, Benedictinas de San José, Burgos, July 2012.

19 See Chronicle, 18 October 1920, 15 November 1920.

20 Frances Lannon, 'Identity and Reform in the Second Republic', in A Companion to Spanish Women's Studies, ed. X. de Ros and G. Hazburn (Woodbridge, Suffolk: Tamesis, 2011), 275.

21 Lannon, 'Identity and Reform', 275. 
They all prayed in Latin, but English was utterly mysterious. The abbot looked above all for 'good will and strong vocation' ${ }^{22}$ it was 'being faithful to the call of God' that would fuel a sense of purpose in working hard 'for the missions'. ${ }^{23}$

Through this period Spain held strongly to an ideal of women as the 'angels of the hearth' (angel del hogar) at the heart of households headed by men: fathers, brothers, husbands. According to the Spanish Census of 1930, fewer than three out of every 10 single women earned an independent income; and of every three who did work outside the home, one was in domestic service. ${ }^{24}$ Compared to these averages, it is interesting to notice that the first New Norcia sisters included a higher proportion in formal employment (five of the 11 so far as we know), all as domestics. What the abbot commended to them as their 'daring project' ${ }^{25}$ traded the family home for a wider domestic sphere.

Overall, both church and culture endorsed the choices these young women were making. The institutional church was robust in the rural north of Spain; parishes and religious orders flourished in the peasant communities, and the Benedictine presence in the landscape went back centuries. ${ }^{26}$ The anticlericalism that marked the cities and the subsistence farming of the south had not bitten so deeply in these areas where networks of community banks and agrarian co-operatives were fuelled by strands within Catholicism that were socially inclusive and economically alert, though not typical of the Spanish church. ${ }^{27}$ The tradition of Spanish missionary endeavour and New Norcia's own particular history were both claimed in Burgos. It was a small step to include young women in the regular contingents of young monks who sailed for New Norcia.

22 Catalan to Rev. Mother Carmen Corral, affirming Andrea Pardo, 20 July 1933, NNA 01434/191.

23 Catalan to Matias Catalan, concerning Pilar, 18 and 21 July 1933, NNA 01434/171, NNA $01434 / 180$.

24 Lannon, 'Identity and Reform', 275.

25 Catalan to Isidora Garcia, 15 July 1933, NNA 01434/170. (Garcia did not join the group.)

26 The first Benedictine community established outside Italy is said to be San Pedro de Cardeña near Burgos, with firm documentation from 902 and a tradition dating foundation in the sixth century. 'Monasterio de San Pedro de Cardeña: Historia', www.monasteriosanpedrodecardena.com/ mspc-mon-historia.html; accessed 3 April 2018. See also Martial Besse, 'The Spanish Benedictines', Downside Review 16 (1897): 268-97.

27 William J. Callahan, 'The Spanish Parish Clergy, 1874-1930', Catholic Historical Review 75 (1989): 407, 417, 410. The Record reported on Spanish co-operatives approvingly; see, for example, the abbatoir in Salvado's home town of Tuy, Record, 14 November 1925, 7. 
On the other hand, the assumptions built into Abbot Catalan's decision to recruit in Spain are also important to notice. The abbot looked for Spanish women to expand the numbers. He did not build on the Benedictine connection with the Sisters of the Good Samaritan who were active in the east of Australia, nor did he seek to extend the involvement of the Josephites who were already at New Norcia and in other schools through the territory of the abbey nullius. He also looked to the networks around Benedictine communities, not teaching or missionary congregations in Spain. Although there were some contacts at least as late as 1929 through Teresa Roca with the Teresians, ${ }^{28}$ there was no question of reviving that connection or of establishing any link with another missionary teaching group. Officially, Abbot Catalan denied any familiarity with the Teresian history, reporting only 'it was said' that they had come and gone in the time of his predecessor. ${ }^{29}$ The original decision taken at New Norcia under Torres had been for religious women who were Spanish and Benedictine. Those priorities were even firmer under Abbot Catalan.

The unresolved issue was around the status of the community the women were joining. The abbot's contacts in the convents reported that more than one potential member was confused about exactly what kind of group was at New Norcia. There were no clear answers to this question. The girls saw the symbols of traditional religious life, but New Norcia's structure for women was officially non-existent; essentially they were being asked to work informally alongside the missionary monks. Abbot Catalan required the hopeful new members to bring clothes that suited European postulants: two black dresses (one wool; one lighter, it could be silk), closed-toe black shoes with a small heel, stockings (not transparent ones), handkerchiefs and four changes of underwear. He would cover the cost of these clothes, alongside passports and documentation, if necessary. ${ }^{30}$ Unlike the established congregations, he did not ask families for a dowry. But confessors reportedly advised against joining a community that was so hard to explain, and Catalan lost candidates whose resolve had seemed firm to more standard communities. He found it especially galling when one girl joined the Dominicans, whom she got to know while staying with their community in Barcelona waiting for the boat

28 Abbot Catalan to Reverend Mother, Teresian Convent, St Gervase, Barcelona 14 January 1929: 'I have your address from Sister Teresa Roca, Benedictine Oblate of this Mission long known to you', NNA 01430/5.

29 Catalan to Rvd M. Carmen Mascaró, 24 April 1930, NNA 01431/94.

30 Mosso, 'Your Very Affectionate Father', detailing, for example, Catalan correspondence 1920s, NNA 01341. 
to New Norcia. While others who changed their mind received letters observing that a choice that was not God's will would have been a mistake all round, and wishing them well, in this case the abbot severed all ties. He returned her travel documents to her family through an intermediary, suggesting her father use them 'as he thinks fit'. ${ }^{31}$ The stress of the international expeditions touched the abbot too.

At New Norcia, the Chronicle's own confusion about how to refer to the new missionary women also points to the fragile status of the group. Through the decade, they were given various titles. They were sometimes absorbed into the community of Benedictine monks (as in September 1920, when the diarist reported good relationships between three, and only three, communities in town-Benedictine Fathers, Marists and Josephites ${ }^{32}$ or when a report of an invitation to la Communidad, 'the Benedictine Community', included 'Sister Maria (oblate) and the native girls ${ }^{33}$ ). At other times they were variously referred to as oblatas or specifically female oblates, Oblate Sisters, oblates of (or in) our orphanage, Benedictine oblates, Oblates of New Norcia, girl oblates, sisters, religiosas or female religious, and Spanish sisters. ${ }^{34}$ In correspondence, the abbot referred to them most often as 'Sisters' when writing of them to the monks and by name or as 'the little nuns' in letters to friends and supporters in Spain. ${ }^{35}$ In response, the nuns in Spain who had set the process in motion for the young women asked for news of 'our oblates' and the burgalesas, the women or girls from Burgos. ${ }^{36}$

The single source from the Benedictine women themselves in these years is the heavily edited Notebooks of Sister Felicitas. The three versions of this account (two in English and one in Spanish) vary in subtle ways, especially between Spanish and English, but overall they share a concern for discretion. In the three sentences about Felicitas's own arrival in 1921, the Notebooks used the range of terms that appear in New Norcia's

31 Catalan to the Abbess of Estrella, 23 November 1925, concerning Deogracias Mangado, NNA 01358.

32 Chronicle, 30 September 1920.

33 Chronicle, 9 October 1920.

34 Chronicle, 15 November 1920, 19 February 1921: 'Oblatas Benedictinas'; 16 October 1920: 'Oblata de San Benito'; 10 September 1920: 'Hermanas Oblatas'; 25 January 1924: 'hermanas españolas'; 23 December 1925: 'Oblatas en nostra orfanata por las indigenas'; 15 August 1928: 'chicas oblatas'; 16 August 1928: 'oblatas de Nueva Nursia'.

35 Catalan to Salinas, 30 August 1921, NNA 01423/95; Catalan to Sosa, 17 March 1926, NNA 01427/21; Catalan to Felisa Escudero, 28 September 1922, NNA 01424/71; 25 January 1924, NNA 01426/17; 22 February 1924, NNA 01426/38; 10 October 1926, NNA 01427/121.

36 Calderón to Catalan, 19 July 1925, trans. David Barry, OSB, original NNA 01341, translation NNA 05496. 
other sources to introduce the sisters. Tellingly, the later generation also preserved, in broken English, the shock that Felicitas felt on her arrival and her disappointment that the convent was so different from the large communities that had encouraged her to join the mission:

In February 1921 Abbot Catalan was returning from Spain; with him were 11 young boys, students for the Benedictine community, and two young girls from Burgos, to join the small group of the Benedictine Oblates. They were Srs. Felicitas Pampliega and Margaret Perez. When they arrived at New Norcia and saw the small group they were discouraged as they thought to find a community. ${ }^{37}$

Girls, from Burgos, becoming oblates, sisters, with new names, and hoping for a community. The narrative of the Notebooks does not pause at the 'discouragement' evoked by New Norciàs fragile group but pushes on immediately to a statement of faith in the community they found and in the task they had already claimed as a godly calling by the journey they had made. Their decisions are attributed to the same twin love of God and the Aborigines that had drawn Maria Harispe. ${ }^{38}$ A string of metaphors tries hard to cover the experience:

But coming from far, their decision was to abandon the things of this world for God's love and the aborigines. They found many obstacles on their way. But with God's grace they triumphed. [The] example of the other Srs. before them like the star that shines in the darkness would be for them the guiders [sic]; and persevering on their footsteps one day will come when reaching to the submit [sic] god [sic] will reward according to their merits. ${ }^{39}$

God was at work, the Notebooks affirm, and things were not as they imagined. While the text rallies to insist that the community did enlighten and guide them to holy lives, the anxious question of what it was that they had really come to ran through the decade unresolved.

What was it that the 16-year-old Felicitas had expected? 'A bigger community, more nuns': the testimony of later sisters is adamant. ${ }^{40}$ Felicitas, like Margaret, had been a domestic at the Cistercian community

37 'Benedictine Missionary Sisters: Foundation and Progress', unpublished typescript summary in English from the notebooks of Sister Felicitas Pampliega c.1921-c.1967, ABTM (hereafter Notebooks in English, Madrid).

38 See Maria Harispe's letter to Henry Altimira, 6 June 1908, NNA 01717/82, discussed in chapter 2.

39 Notebooks in English, Madrid, n.p.

40 Visitación Cidad, Teresa González, Interview, Madrid, 6 October 2010. 
of Las Huelgas, and the ancient heritage there shaped her expectations. But none of the examples of religious life from around Burgos would have looked as idiosyncratic as the community at New Norcia. Six members were required before a community could be recognised officially by Rome, and New Norcia had not reached that minimum even with the new arrivals because Mother Elias was not technically a Benedictine, and, in any case, the community remained an informal house of oblates. In Spain the communities of nuns had been less affected by the anticlericalism of the nineteenth century that closed many houses of Benedictine men. Some had lost land and possessions, but their convents were seldom abandoned. The 1889 Spanish Civil Code, based on the Napoleonic Code of 1804 and only briefly repealed under the Second Republic (1931-36), defined citizenship as essentially masculine. ${ }^{41}$ Nevertheless, women in religious communities had an institutional status in the church that stretched categories of family and state. The historic stone convents remained landmarks of stability and tradition and, to a certain extent, of women's agency and enterprise.

At Las Huelgas, founded by royal patrons in $1187,{ }^{42}$ Abbess Maria de la Gloria Calderón governed her Cistercian community in a tradition that gave her privileges akin to a diocesan bishop, including episcopal staff and mitre as symbols of authority. The opening out of the community beyond noble women, and the end of provisions that allowed personal maids for the choir sisters, still left family insignia in place over the prayer stalls, the twin tombs of Eleanor Plantagenet and Alfonso VIII in the chapel's central nave, and a long tradition of village girls who joined the community both as lay sisters and as domestics without vows to take the weight of the housework. ${ }^{43}$ Five of the earliest of New Norcia's sisters made contact with the mission through the regal austerity of this community at Las Huelgas. In 1925 Benita and Escolastica were domestic workers 'within the enclosure' ${ }^{44}$ like Felicitas and Margaret before them. In 1928 Maria Cidad was also working there, ${ }^{45}$ and Hildegard and Matilde left their families in Tapia and stayed briefly at this monastery, too, before their journey to Australia. ${ }^{46}$ The Cistercians were in the southwest corner of

41 Lannon, 'Identity and Reform', 275; Sarah Leggott, The Workings of Memory: Life-Writing by

Women in Twentieth-Century Spain (Lewisburg, PA: Bucknell University Press, 2008), 35-37.

42 Valentin de la Cruz, El Monasterio de Las Huelgas de Burgos (Léon: Editorial Everest, 2005), 6.

43 de la Cruz, Las Huelgas, 30.

44 Calderón to Catalan, 19 July 1925, NNA 01341.

45 Sr Maria Gratia Balagot, email correspondence, 13 July 2014.

46 Catalan to Abbess Filomena, 1 July 1928, NNA 01429/66. 
the town, near the railway station. Abbot Catalan arranged the departure of the trio in 1928 with the new Abbess Filomena and, with attention to both propriety and economy, reminded her that all three should set out for the station wearing veils, 'as this is the moment to recognise that they are like religious postulants, and also so they will not have to pay more than half-fare'. ${ }^{47}$

Las Huelgas had unique privileges, but it was not the only Spanish community to make solemn claims. Sister Lorenza Diez at Palacios de Benaber passed on news that the abbess at Catalayud had been invested with staff, ring, and pectoral cross. ${ }^{48}$ At Palacios de Benaver itself, the Benedictine monastery of San Salvador had a history first documented in $1231 .{ }^{49}$

Over six centuries of tradition endorsed the community where Mother Josefa Ramos had gathered Felicitas and Margaret to 'their new life, ${ }^{50}$ where Francisca heard about New Norcia from her Benedictine aunt, and whose abbess supported the 16-year-old's campaign for her father's consent to leave the country, ${ }^{51}$ and where Sr Lorenza would assemble documents and coordinate the departure of later groups. ${ }^{52}$ These Benedictines had weathered the attacks on monastic foundations with minimal disruption and ran a small school just within the walls. It is likely New Norcia’s Sisters Margaret and Ludivina learnt to sew and to read there. Possibly Felicitas travelled the 7 kilometres from her village to attend as well, before she took the post as a domestic at Las Huelgas. All the women in farming families were familiar with hard work on the land as well as domestic work. But there was nothing that prepared Felicitas for the mute isolation and loss of identity she felt out in New Norcia's paddocks clearing the ground for ploughing. It was her record of tears in these early days at the mission, 'every day picking stone, every night crying, all the time crying, ${ }^{53}$ that so embarrassed the later generation of sisters and led most directly to the destruction of the original Notebooks.

47 Catalan to Abbess Filomena, 1 July 1928. For the location of the train station, see Luis Santos y Ganges and José Luis Lalana Soto, 'La antigua estación de Burgos y el precario papel del patrimonio en los proyetos urbanos y arquitectónicos', arquitecturaviva.com; accessed 20 October 2019.

48 Lorenza Diez to Catalan, 5 and 16 November 1947, trans. David Barry, OSB, NNA 01341.

49 Luciano Serrano, Una fundación medieval de la Casa de Lara el Monasterio de Palacios de Benaber, Burgos, 1941, digital copy (Valladolid: Junta de Castilla y León, Consejería de Cultura y Turismo, 2009-10). See also Monasterio de San Salvador, www.benedictinaspalacios.com/.

50 Abbess Josefa Ramos to Catalan, April 1921, trans. David Barry, OSB, NNA 01341.

51 Catalan to Abbess Carmen Corral, 29 July 1933, NNA 01422-01436D/191.

52 Diez to Catalan, 16 November 1947, NNA 01341.

53 Teresa González, Interview, Madrid, May 1999. 


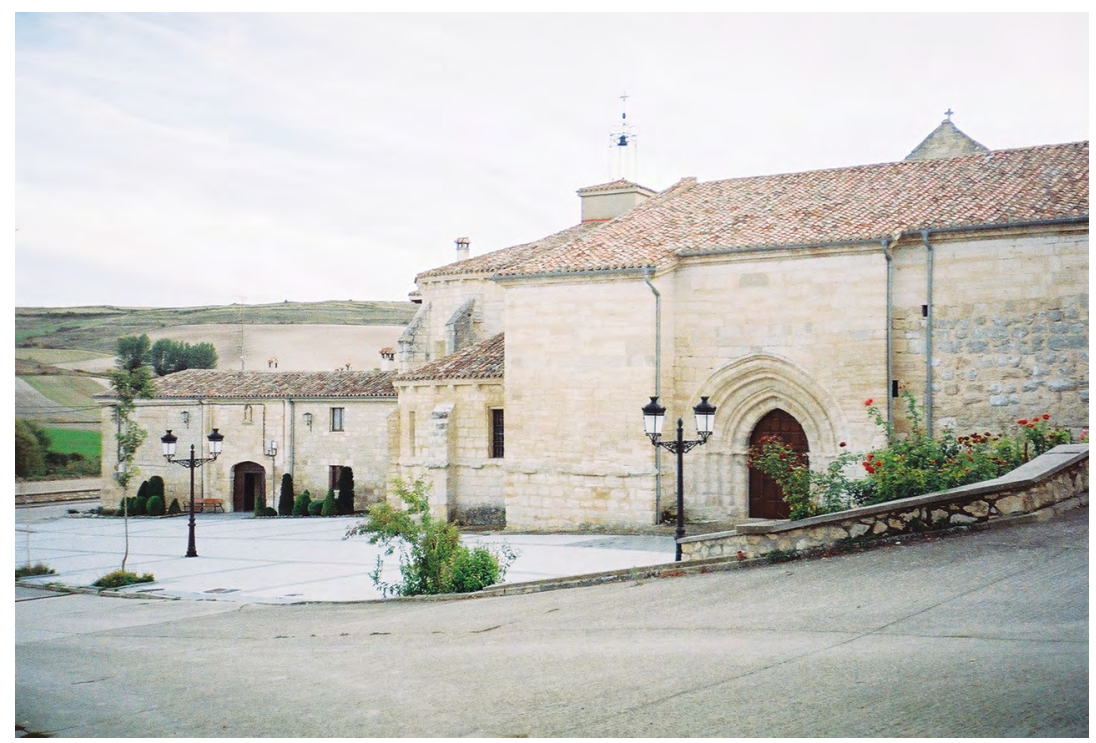

Figure 5.3: Monastery of San Salvador, Palacios de Benaver, Burgos.

Source: Photo by John H. Smith. Author's collection.

\section{'Just waiting ... for our broken inglish'}

The young woman's failure of courage was edited out, as 'anyone might read it [and misunderstand] ${ }^{54}$ but if we stay with the Notebooks' account of the 1920s we are jack-knifed through doubt towards security. Felicitas poured out the words we no longer have, but both the memory of the sisters who knew her and the remnant of her lament suggest that she wrote so much in Spanish chiefly because she was speechless in English. ${ }^{55}$ As she found a voice in English, her trauma eased and her confidence in the community increased. Language was not simply acquisition of grammar and vocabulary but the foundation for rapport and authority.

The English versions of the Notebooks have been edited more firmly into an overview of this time. It is significant that even here the initial fear Felicitas felt for the Aboriginal girls at St Joseph's remained in the text. Generations of the sisters knew the shame of having only 'broken inglish' (sic). While we cannot know exactly what Felicitas wrote, the edited end-

54 Teresa González, Interview, Madrid, July 2002.

55 Teresa González and Visitación Cidad, Interview, Madrid, 30 September 2010. 
product shows us clearly what the community thought it acceptable to retain. Weaving between the voice of Felicitas and a later narrator, the Notebooks vividly conveys her stress and alienation. As she and Margaret took over supervision of work in the sewing room, the class stared and waited for Felicitas to speak. The girls' fixed eyes were a strong Aboriginal challenge that even these newcomers knew how to read. It was a test of wills:

Here the two young Sisters in charge of a group of aborigine girls, without knowing how to speak inglish, and how little they like on those days to be under supervision, and discipline; these girls then were waiting to hear some commands of the young Srs; some broken inglish, to have some fun of them perhaps. In the sewing room most of the time they would do nothing of their work, but with eyes fix on them just waiting now and then for our broken inglish. On those days jet [sic] their civilisation and manners still more or less wild, use to fight and quarrel among themselves terribly and useless saying it was a very difficult job to stop them. ${ }^{56}$

The Spanish Notebooks omitted the detail here and chose simply to say they were 'wrapped in countless difficulties with minds completely blank'. ${ }^{57}$

In contrast, Abbot Catalan was cheerful as he reported the progress of the new recruits in letters to Spain. Catalan wrote to Mother Josefa at San Salvador in April 1921, assuring her that the two had made the journey well, without any seasickness and embracing the adventure. He attributed the easy arrival to God and the prayers of the Benedictine sisters: 'How much we have to thank our Lord God for such grace! And our Sisters at Palacios, it is not for nothing that we are grateful to them! ${ }^{58}$ As the Record had told its readers in parishes around Western Australia, and as the Chronicle recorded for the monks, the abbot also reported overseas that the town had been decked out as for a major solemnity for their arrival,

56 'Benedictine Missionary Sisters', handwritten summary from the notebooks of Sister Felicitas Pampliega c. 1921-c. 1967, previously held at the convent of the Benedictine Missionary Sisters, Kalumburu (hereafter Notebooks, Kalumburu), n.p, NNA.

57 'Origen de la Congrecacion de las Hermanas Benedictinas Misioneras de New Norcia, Western Australia' unpublished typescript from the notebooks of Sister Felicitas Pampliega c. 1921-c. 1967, transcribed and edited by Sister Teresa González, Madrid c. 1980, Archives of the Benedictine Missionary Sisters of Tutzing (ABTM) (hereafter Notebooks, Madrid), 9 (envueltas en innumberable dificultados y con la mente complamente en blaco).

58 Catalan to Josefa Ramos, 10 April 1921, NNA 01422/74; Catalan to Felisa Escudera, Barcelona, 28 September 1922, 25 January 1924, 22 February 1924, NNA 01436A/17-38-74. 
with Australian, Spanish and Papal flags across the college buildings, cadets presenting arms, the pupils of the boarding schools lining the path from the monastery to the church, 'and behind these again the children of the native schools'. ${ }^{59}$ The organist played them into the church with the royal march of Spain. After Solemn Benediction of the Blessed Sacrament in the church everyone celebrated with the new arrivals in the 'salon' at the centre of the monastery. The Chronicle remembered an excellent meal and judged 'a most sincere enthusiasm and a most complete happiness reigned'. ${ }^{60}$

\section{In the sewing room and in the bush- tension and community}

The St Joseph's girls had lined the way to the church for the newcomers, but in the sewing room, once the town's festival of welcome had ended, ${ }^{61}$ trust and openness needed to be earned. Four of the 'girls' in the sewing room at St Joseph's in 1921 were young women in their twenties, 'tall, strong, physically big', the Spanish account reminds us, ${ }^{62}$ older than either of the two sisters 'in charge', and connected through shared history and family to the dozen or so younger girls. In 'do[ing] nothing of their work' ${ }^{63}$ but 'watching while the others did theirs', ${ }^{64}$ these Aboriginal women had an effective means of protest. Withdrawing their labour was less public than the silence in church of 1907, and perhaps less effective while others (sisters or the younger girls) kept up the work; perhaps the protest was directed specifically to St Joseph's. But whether or not the Aboriginal anger was against the new sisters, the work itself, or their situation at the mission, the two new arrivals were intimidated.

Both the young sisters were good craftswomen. The school system in Spain encouraged handcraft for girls. ${ }^{65}$ In later years, Felicitas organised formal dressmaking lessons, and girls knew they could rely on her talent to restyle

59 Record, 5 March 1921, 2.

60 Chronicle, 19 February 1921.

61 See below, 00.

62 Notebooks, Madrid, 9 (eran altas, fuertes y de gran corpulencia fisica).

63 Notebooks, Madrid, 10.

64 Notebooks, Madrid, 9.

65 José María Borrás Llop, Historia de la infancia en la España contemporánea, 1834-1936 (Madrid: Ministerio de Trabajo y Asuntos Sociales, Fundación Germán Sánchez Ruipérez, 1996), 349; Consuelo Flecha Garcia, 'Education in Spain: Close-Up of Its History in the 20th Century', Analytical Reports in International Education 4 (2011): 17-42. 
donated clothes; ${ }^{66}$ Margaret's knitting extended to at least one full-length wedding dress and is still treasured. ${ }^{67}$ They were very different: Felicitas the future superior and Margaret the group's longest-serving novice, but both were idealistic and apparently dumbfounded by their reception. The Spanish account described more of the conflict as the weeks wore on: the older girls used to run away and leave the work rather than take 'advice' from the sisters, these 'youngsters' (jovencitas) ${ }^{68}$ the conflict between those younger Aboriginal girls who worked and the older ones who did not was physicaloften there were fights the sisters could not stop, which left the young women (perhaps all of them?) 'useless and bleeding. ${ }^{69}$

Visitors who had seen St Joseph's residents as models of quiet good behaviour would have been shocked. Embroidery was already a speciality of the school, and accolades continued through the 1920s and 1930s for work so highly skilled that 'superlatives alone do justice to its excellence' ${ }^{70}$ It is hard to imagine the "quantities of fine lace"1 and other delicate creations coming from anywhere except a peaceful workshop. Certainly the reports in the press implied this, and the traditions of collaboration and pride in good craft come through the oral record too. ${ }^{72}$ The guest from Government House in Perth who wrote in 1923 that she would treasure the tablecloth embroidered with black swans 'so quickly and so well' as a favour by someone 'kind and clever'73 clearly had no idea. Perhaps it was all over by then, but a year earlier the sewing room was the setting for a power struggle made worse by a language barrier.

66 Mary Nannup (Philomena Drayton), Interview, Moora, March 1999; Anne Moynihan, Interview, North Perth, March 1999.

67 The dress was made for Rose Willaway, who wore it when she married Preston Narkle in 1974.

68 Notebooks, Madrid, 9 (aconsejarlas se acababan mas y se largaban con todo el trabajo).

69 Notebooks, Madrid, 9 (con frecuencia ... saliendo malparadas y sangrando unas y otras).

70 St Ildephonsus College Magazine, 1929, 7; Daily News, 8 October 1929, 2; Recorder (Port Pirie), 14 February 1938, 3. On the work sent to the Missionary Exposition in Rome, Catalan to Abbot Romauldo Simo, 2 September 1924, NNA 01436A/125; Catalan to Fr Salinas, 10 September 1924, NNA 01436A/127; and high standards at Yarrawindah Show, St Ildephonsus College Magazine, 1927, 74.

71 M. Edward Dasey, The Story of the Regional Missionary and Eucharistic Congress, Newcastle, NSW (Newcastle: Specialty Publications, 1938), 59.

72 Mae Taylor, Interview, New Norcia, 2003; Sheila Humphries, Interview, New Norcia, May 1999; Veronica Willaway, Interview, Nebraska, 9 July 2013.

73 Katharine Campion to Sr Gertrude, 27 December 1923, NNA 01123. 


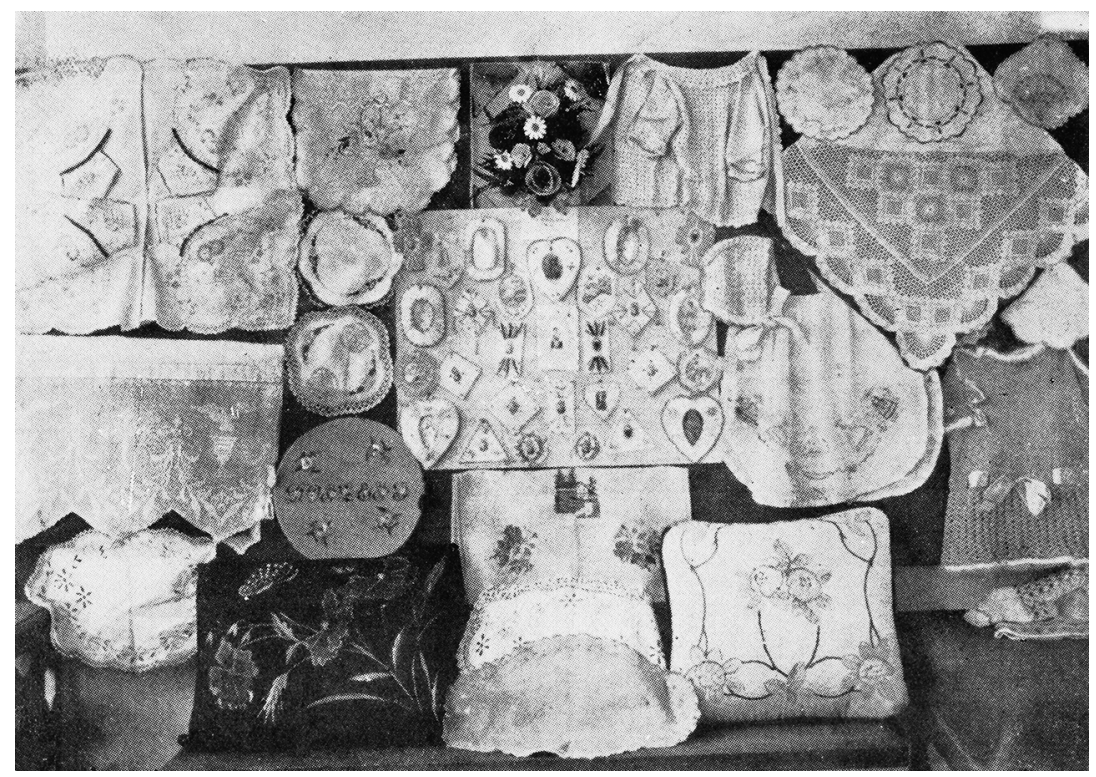

Figure 5.4: Display of needlework by St Joseph's Girls, St Ildephonsus College Magazine, 1929, 7.

Source: NNA.

We hear nothing of a resolution. The English version of the Notebooks pushes the narrative through the initial stand-off and on to better things. There is a leap forward to a picnic scene in the spring of 1924. Now the new missionaries are in charge of the excursion; symbolically, the land is blossoming and abundant. The account is alive to the traditions of the Aboriginal children, and the young sisters take their day in the bush with them 'joyfully' in stride. The Spanish summary of the Notebooks adds that the change was specifically because they could now chatter away enough in broken English (chapurrear) that they felt both comfortable and useful (consoladora y provechosa) $:^{74}$

One of those days of spring in New Norcia's bush, we two were sent for a picnic with the children, and as usual this [sic] children spent their time picking wildflowers, cutting a tree with honey. On those days no one would have bee boxes. We pass the day joyfully in the bush with the children and came home that day about 8.30 in the evening, this our first picnic day, quite satisfied of the day. ${ }^{75}$

74 Notebooks, Madrid, 9-10.

75 Notebooks, Madrid, 7-8. 
The institution had grown to include 45 girls. If the boys from St Mary's had joined the occasion there would have been 76 children with Felicitas and Margaret that day. ${ }^{76}$ The regular outings in the bush are a recurring motif in the oral evidence. This is the only account of a picnic in the sisters' written narrative, but here as elsewhere it was an occasion of harmony and community.

Yet once again the Notebooks shifted gear quickly, replacing tranquillity with a sombre mood. Met on their return from the bush with news that Maria Harispe, 'the foundress', was grievously sick, the community faced the trial of her treatment for cancer ('an internal growth close to the heart ${ }^{37}$ ) in Perth and the eventual loss of hope in her recovery. The Chronicle records her treatment in regular entries about her trips to hospital. ${ }^{78}$ The Spanish Notebooks include Maria's 'unspeakable suffering' and an incident during her illness when a violent fight between the older girls made her cry out, 'I die without seeing any fruit!'79 In the English version there is no such distress about the work. Instead, the focus is on the community's sorrow. Maria's illness left God as the only steady point: 'we were left like orphans, and we have to say now "My God and my all"'. ${ }^{80}$ When Maria died the following spring, aged 44, the English account was precise and, for all its phonetic spelling and poor grammar, it gave details that disappeared in the Spanish copy about the time and the order in which the groups in the town came to mourn, before reiterating Maria's status as 'Mother':

During this weeks, Sr got very sick and 10 [minutes] after receiving Holy Communion at 7.20 am died on the 16th of November 1925. As soon as possible three Benedictine Fathers came to say prayers for the death. They rung the church bells for the death, Masses were offered for her eternal rest. As soon as the natives knew Sr. pass away they all came around her remains praying to see her, that which had been a Mother to them for 15 years. The Josephine Sisters [from St Gertrude's] also came to pray around her remains.

76 New Norcia Annual Return, 24 September 1924, 'New Norcia Mission - Subsidy and General', State Records Office of Western Australia (SROWA) S2030 cons993 1926/0350. See also Appendix 1.

77 'Sister Mry [sic] Harispe', New Norcia Sunday Leaf, 18 October 1953.

78 Chronicle, 25 April 1925, 13 May 1925, 27 June 1925, 8 July 1925, 30 July 1925, 25 August

1925, 25 September 1925, 13 November 1925, 16 November 1925, 17 November 1925.

79 Notebooks, Madrid, 11 (sufrido ... indeciblemente) (muero sin ver ningun fruto).

80 Notebooks, Kalumburu, n.p. 
Her remains and her grave was covered with beautiful flowers. She was loved by everyone, as she was a Mother to everyone. So we were without a Mother. ${ }^{81}$

Of course, there were other mothers in town, Aboriginal women in the cottages and the surrounding bush and also white women on the surrounding farms. But in the English version the young sisters had lost the figure who had represented their particular brand of a shared public maternity lived in the name of the church. The Spanish account is briefer here, noting 'her death was felt deeply by all' and especially by the missionaries for whom Maria was 'a physical and spiritual force'. ${ }^{82}$ In both languages, the relationship of spiritual motherhood, framed by assumptions of a shared Catholic culture, was used to identify the missionaries with the people, and the people with the missionaries.

The Chronicle also stressed the shared mourning for Maria. Her body was moved to the church and the 'native orphan girls' kept vigil through the afternoon and night. The funeral the next day saw the whole community turn out 'in full' (en peso, literally by weight in Spanish), all four schools, the Benedictine community, 'all the workers, and several of the neighbours nearby ${ }^{83}$ Her obituary, published in the Record as well as in the magazine of St Ildephonsus' College, was in keeping with the tributes offered to nuns in other congregations, ${ }^{84}$ honouring her simplicity, duty and sacrifice, 'in the carrying out of what was, humanly speaking, an almost impossible task ... [that had] won her the love and admiration of all within the Mission'. ${ }^{85}$ The Record gave her the title 'Friend of Native Orphan Girls' and stressed their need, showing the residents gathered around Maria, more informally than a decade earlier, still in boots and lace collars but in front of a broken wall. It was an image of sacrifice and hardship rather than triumph.

81 Notebooks, Kalumburu, n.p.

82 Notebooks, Madrid, 11 (su muerte fue muy sentida por todas) (especialmente por los Hnas que perdian fuerza fisica y esperitual).

83 Chronicle, 17 November 1925.

84 Record, 12 September 1925, 13 (Sr Marie de Chantal, Fremantle); 19 December 1925, 21 (Sr Marie Celestine, Albany).

85 Record, 19 December 1925, 11; St Ildephonsus College Magazine, 1925, 57. 


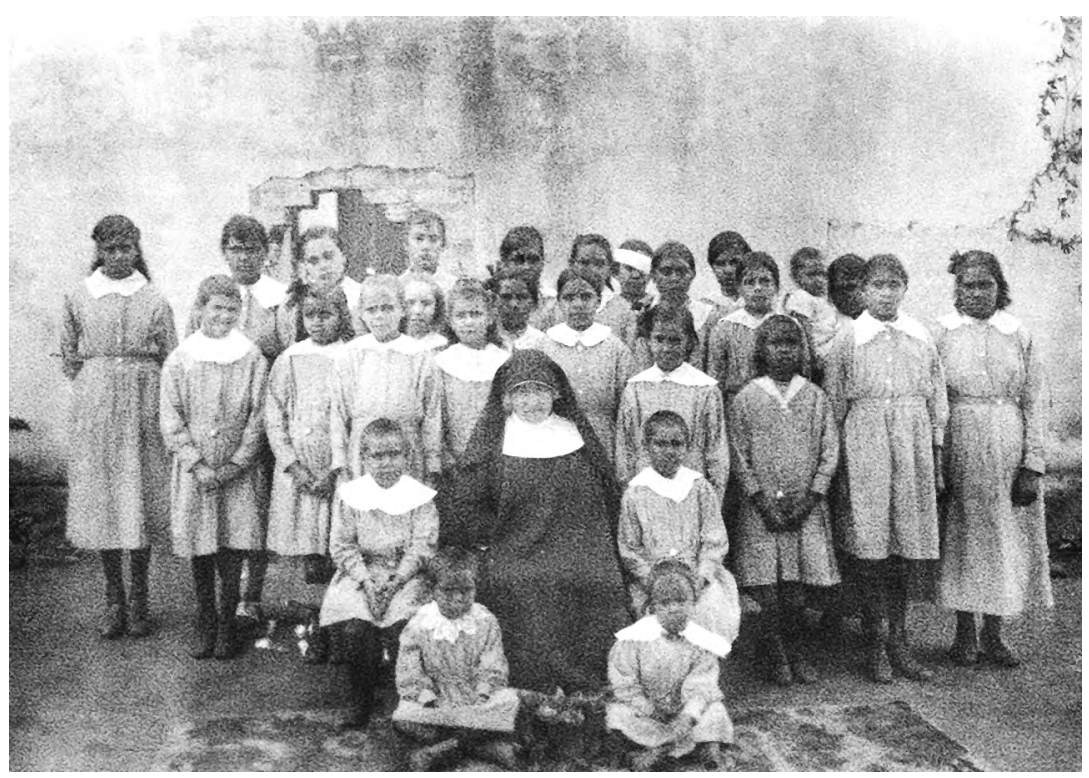

Figure 5.5: Maria Harispe, c. 1925; the photograph that accompanied her obituary in the Perth Record.

Source: NNA W7-A3-4-498.

The Notebooks, however, concluded the account of her loss by focusing on the sisters. There is a hint of her suffering bearing fruit in the arrival of new members. In the 18 years since she had travelled from Spain with the Teresians, Maria Harispe had been a stable presence as the band of missionary women dispersed, reconfigured and endured. Hearing before her death that Benita and Escolastica would travel with the abbot to join the group and take the numbers above the canonical requirement of six, the Notebooks concluded Maria's life by recording her hope that: 'Now our desire will be realised to form a little community' ${ }^{86}$ Maria had wanted to pioneer the house in the Kimberley. It was therefore fitting that the future of canonical status she hoped for would be firmly linked to the need for Benedictine women at the Drysdale River Mission. Perhaps only at New Norcia would the decision have been taken to realise this hope through a link with Belgium. 


\section{Made in Belgium: Spanish Benedictine Missionary Sisters for New Norcia and the Kimberley}

It was no secret among the Benedictine sisters that a Kimberley mission was talked about, but it is only Abbot Catalan's letters to the missionary monks in the north that make it clear how seriously the sisters' presence was being sought in the early 1920s. Both the recruiting of new members and attention to the group's canonical status were given impetus by the need for the community to be large enough and secure enough to send sisters to join the monks in the north.

The plea for women to join the mission effort was prompted by the increasing number of children at the Kimberley mission and turned on assumptions about both race and gender. When the Benedictines first established a camp at Pago Pago near the Drysdale River in 1908, and through the first decade when tension between the local Gwini people and the monastics made the future of the mission doubtful, the monks puzzled that there were no children among the people and remarked on the small number of women. ${ }^{87}$ As trust grew, and sporadic attacks ceased, ${ }^{88}$ the concern to preserve the Aboriginal population and to see it increase was a mission priority. When the first baby, a girl named Mary Pandilow, ${ }^{89}$ was born in the mission in 1918, the call went out for sisters to exercise a spiritual maternity. The monks' letters do not mention the Aboriginal mothers or wider family, although children were predominantly cared for in the Aboriginal camp, even after the arrival of the sisters when a dormitory and institutional care of the children developed. ${ }^{90}$ As at New Norcia before the Teresians, Aboriginal women at the Kimberley mission exercised responsibility in relation to the dormitory, but the role of Matilda Morechi, and later Mary Pandilow herself, was a stopgap in the absence of the sisters. ${ }^{91}$ Father Seraphim Sanz, the later and longestserving Benedictine superior at Kalumburu, summarised the arrival

87 Christine Choo, Mission Girls: Aboriginal Women on Catholic Missions in the Kimberley, Western Australia 1900-1950 (Crawley, WA: University of Western Australia Press, 2001), 72-73; Seraphim Sanz de Galdeano, Memoirs of a Spanish Missionary Monk (Carlisle, WA: Hesperian Press, 2006).

88 Ian Crawford, We Won the Victory: Aborigines and Outsiders on the North-West Coast of the Kimberley (Fremantle, WA: Fremantle Arts Centre Press, 2001), 182-86.

89 'Biographical Cuttings on Mary Pandilow, First Child to Be Born at the Old Pago Pago Mission', National Library of Australia, nla.gov.au/nla.cat-vn1991118; accessed 31 August 2019.

90 Choo, Mission Girls, 164-65.

91 Crawford, We Won the Victory, 58; Choo, Mission Girls, 166-67. 
of the Benedictine women pithily: 'When there were no children in the Mission the Sisters would have been a burden; with children they were indispensible. ${ }^{92}$

Recognising a new necessity, Abbot Catalan's negotiations with the monks in the Kimberley about when and under what conditions the sisters would be sent were also marked by assumptions about gender and race. On the one hand, the women were deemed essential for the outreach to children and, on the other, the conditions in the Kimberley would be a particular problem to the health of European women. Later, the record gives us glimpses of the sisters' own understanding of their role. At the outset we can see only the discussion between the monks.

Shortly after Felicitas and Margaret arrived in New Norcia in 1921, the abbot responded to a letter from Fr Raimundo Salinas at Drysdale River. Fr Raimundo had admitted that his happiness on account of these new Benedictine sisters was 'watered down' ${ }^{\prime 3}$ because there was silence about sisters for the north. The abbot reassured him: 'I can see very well how useful it would be to have religious women there. ... I haven't changed my mind, it is the same: to send the Sisters as soon as possible..$^{94}$ But the possibility was itself watered down as the abbot gave instructions about conditions that needed to be met.

First, there must be enough sisters, and, second, the monks must prepare properly for them. The abbot required a convent to be built separate from the still-to-be-completed monastery, including at least three cells to accommodate at least three sisters, a refectory and 'one or two rooms more'. ${ }^{95}$ Then they must also establish a herd of goats. As early as 1919, Catalan had asked advice on tropical goat-herding from the Durack family at Argyle Station. ${ }^{96} \mathrm{He}$ wanted these animals to safeguard the sisters' health as women were 'not so resilient as men, even less in the tropics'. ${ }^{97}$ By providing red meat, the goats would prevent anemia. Probably the threat of the tropics to Europeans, including the Mediterranean Spanish, was a familiar enough idea, ${ }^{98}$ but who among the local game hunters would

92 Seraphim Sanz, OSB, personal correspondence, June 2000.

93 Catalan to Salinas, 30 August 1921, NNA 01423/95, paraphrasing Salinas's letter, which is not extant.

94 Catalan to Salinas, 30 August 1921.

95 Catalan to Salinas, 30 August 1921.

96 M. Durack replied to Catalan, 20 November 1919, NNA 01441.

97 Catalan to Salinas, 30 August 1921.

98 See D. Arnold, 'The Place of "the Tropics" in Western Medical Ideas since 1750', Tropical Medicine and International Health 2 (1997): 303-13; Alison Bashford, Imperial Hygiene: A Critical History of Colonialism, Nationalism and Public Health (London: Palgrave McMillan, 2014). 
not have wondered about the particular need for goats? (As it turned out the flock, once established, was valued more for its milk and cheese. ${ }^{99}$ ) Abbot Catalan invoked Sr Maria Harispe as the Reverend Mother to warn the monks she would 'investigate' to ensure that the sisters would live in 'some comfort and decency'. ${ }^{100}$ Would she have been offended that he urged Fr Salinas to act 'before they can snub us' over a poor building? ${ }^{101}$ Whether or not the abbot was entirely convinced of the conditions he set, he assured Fr Salinas that another year was all that it would take 'to do everything calmly, so it will be more perfect'. ${ }^{102}$

When four years had passed and Benita and Escolastica were being welcomed to New Norcia, it was a letter from Fr Rosendo Sosa that prompted further clarification from the abbot. Apparently Sosa suggested working with the Sisters of St John of God, who had been in Beagle Bay near Broome since 1907. The girls from Drysdale River were sent to their school, with significant trauma for the community at Pago Pago. ${ }^{103}$ It made sense to suggest these sisters could be involved further north. But Abbot Catalan dismissed the idea as 'dreaming' and likely to undermine the Benedictine community. ${ }^{104}$ The 'others that are not ours' would be 'quibbling' (quisquillosa) and lack self-denial. He had heard of trouble in the Broome and Beagle Bay communities and had been shocked by stories that 'these good Sisters asked the [Pallotine] Fathers for some sort of salary for their work'. ${ }^{105}$ The Benedictine family of missionaries worked by different expectations. Catalan would not be paying wages.

In these letters of 1926, the abbot pointed out that Maria's recent death had 'left a big gap at the Orphanage', ${ }^{106}$ but he held out the hope that the two young newcomers might be leaders among the sisters, 'when they have a few more years' ${ }^{107}$ It would 'not be too long' ${ }^{108}$ and he would be able to divide the sisters between New Norcia and the Kimberley. The vague timeline reflected the fragility of the enterprise.

99 Maria Gratia Balagot, Visitación Cidad and Teresa González, email correspondence, 26 July 2014.

100 Catalan to Salinas, 30 August 1921, NNA 01423/95.

101 Catalan to Salinas, 30 August 1921.

102 Catalan to Salinas, 30 August 1921.

103 See Mary Pandilow's story in Crawford, We Won the Victory, 55-58.

104 Catalan to Sosa, 17 March 1926, NNA 01427/21.

105 Catalan to Sosa, 17 March 1926.

106 Catalan to Sosa, 17 March 1926.

107 Catalan to Sosa, 17 March 1926.

108 Catalan to Sosa, 17 March 1926 (paréceme que no tardaremos en tener las suficientes para dividarlas). 
A month after Fr Rosendo proposed collaboration with the Sisters of St John of God, Abbot Catalan made enquiries to secure the future of the congregation as a specifically Benedictine venture. Catalan wrote (in Italian) to the Belgian abbot Theodore Neve to remind him that 'one day at the meeting at San Anselmo last autumn' ${ }^{109}$ he had promised to send copies of the constitutions for some Benedictine oblate sisters. Abbot Catalan was vague. The group were 'Oblate Nuns of St Benedict or Missionary Sisters of the Order of St Benedict', ${ }^{110}$ but to have copies of the constitutions would be a special favour. Neve's house of St André in Bruges had been founded by the Belgian Abbey of Maredsous as a training centre for the missions and was rather controversially designated a 'monastery for the missions' in its own right. ${ }^{111}$ Abbot Neve in turn had founded the Benedictine Missionary Sisters, establishing them at nearby Bethanie in $1921 .{ }^{112}$ These sisters were focused on assisting the work of missionary monks in the Belgian Congo. They would have been an interesting model for the New Norcia sisters, but it seems that Abbot Catalan never received or was not impressed by their constitutions. At least, nothing was done about the canonical status of the oblates at New Norcia until, in 1932, a three-page note at the back of the journal Revue Liturgique et Monastique, published by Maredsous, prompted the abbot to write again to Belgium. This time the author he contacted was Fr Andre Schyrgens, a monk at Maredsous itself, who had established a 'new institute' of women, formally professed as sisters, living the Benedictine spirit not as monastics but like oblates in the world'. ${ }^{113}$ Abbot Catalan was keen to know more, as he told Schyrgens: 'I deduce from the details of the Sisters and their work, that this congregation of oblates is exactly what we need to have in New Norcia'. ${ }^{114}$ Probably Abbot Catalan remembered his previous discussion about the Belgian missionary oblates at Bethanie, or possibly he confused this second congregation at Maredsous with the first, but Schyrgens's article made no mention of missionary work as such. The community at Emmaus House in the grounds of Maredsous was founded by the abbey as a 'practical response' to the need for manual workers in the

109 Catalan to Neve, 18 April 1926, NNA 01422-01436B/26.

110 Catalan to Neve, 18 April 1926.

111 St Andriesabdij Zevenkerken, www.abdijzevenkerken.be/abdij/geschiedenis/; accessed 27 July 2014. The foundation in Bruges was $70 \mathrm{~km}$ from Ypres, where Mother Elias had taught before her move to New Norcia.

112 'Theodore Neve OSB', Idysinger.stjohnsem.edu/@texts2/1910_neve/00a_start.htm; accessed 27 July 2014. See also 'De priorij Onze-Lieve-Vrouw van Bethanië', www.priorijbethanie.be/; accessed 27 July 2014.

113 Andre Schyrgens, 'Notes et Documents, Maredsous—Les soeurs bénédictine de la maison d'Emmaüs', Revue Liturgique et Monastique 17 (1931-32): 243-45; see also Daniel Misonne, En parcourant l'historie de Maredsous (Maredsous: Editions de Maredsous, 2005), 265-74.

114 Catalan to Schyrgens, 10 June 1932, NNA 01433/107. 
kitchen and laundry of their boarding school, a community that would also foster an 'intense interior life' through simple, hidden labour. ${ }^{115}$ Part of the refounding of European monasticism after the French Revolution, Maredsous was publisher of the influential Revue Benedictine from 1884 and founded communities in Brazil (1895) and Ireland (1927) as well as elsewhere in Europe. With memory of the saintly Abbot Marmion still strong, a School of Art as well as the boys' boarding college on site, alongside brewing and cheesemaking, Maredsous was a powerhouse of Benedictine life. Schyrgens foreshadowed the significance of the rich context for fostering 'contemplative, apostolic, liturgical, intellectual and artistic life', ${ }^{116}$ but his new group remained essentially a community of lay sisters for a European monastery and quite different from the earlier group.

Nevertheless, Abbot Catalan proposed enthusiastically that training with this primarily domestic congregation would encompass all that the New Norcia sisters would need. He asked for a copy of the constitutions and proposed immediately that New Norcia might send two of the sisters to Maredsous for formal training with these 'Sisters of Emmaus'. Once formally professed, these two would return to Australia, to establish (in effect) a 'daughter house' of Maredsous but as an independent congregation, thus circumventing the long and difficult process of obtaining approval in Rome for a new foundation of women. ${ }^{117}$ This was administrative thinking that was both extraordinarily convoluted and brilliantly simple—both daft and inspired.

There was no response to the proposal. Five months later, therefore, the abbot followed up his original Spanish letter with a Latin one, proposing the same thing. This time he received a reply. In January 1933 Fr Schyrgens sent not only the constitutions but also, apparently, a report of his discussions with four key players in Belgium. Schyrgens had consulted a canon lawyer (Fr Bastien), the Mother General of the Sisters of Mercy in Heverlé-Louvain who sponsored the community of Oblate Sisters at Emmaus House within the grounds of Maredsous, also the superior of that house itself, and the bishop of Namur. All parties were open to the proposal put by Abbot Catalan. ${ }^{118}$ In March 1933 the abbot exchanged letters with Reverend Mother Marie Thérèse Hyernaux, speaking broadly about the good work she was doing for the missions in Australia and

115 Schyrgens, 'Notes et Documents, Maredsous', 243, 245.

116 Schyrgens, 'Notes et Documents, Maredsous', 245.

117 Catalan to Schyrgens, 10 June 1932, NNA 01433/107.

118 See Catalan's letter of thanks to Schyrgens, 20 February 1933, NNA 01436D/76. 
sending Australian stamps as a favour; by 6 November 1933, Felicitas and Benita were sailing for Belgium. The Notebooks claimed the step as a commencement and identified the journey as central to the foundation of the New Norcia congregation of Benedictine Missionary Sisters. Dressed as postulants of the 'Benedictine Sisters of Mercy of Heverle', ${ }^{119}$ and destined to live with the community at Emmaus House in the grounds of Maredsous for the next two years, Felicitas and Benita left Australia to 'begin to form a congregation of Regular Oblates of New Norcia'. ${ }^{120}$

The whirlwind of activity that saw the connection with Belgium blossom from 1932 had intensified because in August 1931 the conditions the abbot had set for sending the Benedictine women north had been met. There had been a realistic prospect that the abbot would divide the sisters into two houses ever since August 1928 when Hildegard Ruiz, Maria Cidad and Matilde de la Fuente had arrived at New Norcia, and Catalan had met renewed requests from the monks in the north with a firm reminder 'not to insist'. On the other hand, he promised: 'Let us know that the convent is finished and soon you will see the veils'. ${ }^{121}$

Based at Pago Pago, where the water supply was uncertain, and looking to move the whole mission to a better site elsewhere, the monks nevertheless began gathering stone for a convent. The building was well underway by early 1930, but Abbot Catalan was concerned about the design. Safety was an issue. He forbad side doors 'to prevent trouble where we can' ${ }^{122}$ and insisted on windows that would be protected but still allow airflow. Work continued. The abbot left for Europe in October 1930 and did not return until the last day of April 1931. His party included Ludivina Marcos, who brought the number of Benedictine oblate sisters to 10 . The numbers in the south were sufficient; the convent in the north was complete. The abbot wrote to Fr Tomás Gil with a hint of triumph, announcing without further preliminary warning that he was keeping his promise and that the sisters would arrive on 18 or 19 August $1931 .{ }^{123} \mathrm{He}$ also wrote to Bishop Raible in Broome to say they would call in and collect the Aboriginal girls from the school run by the sisters of St John of God as they could now return to Drysdale River. ${ }^{124}$

119 Notebooks, Kalumburu, n.p.

120 Notebooks, Kalumburu, n.p.

121 Catalan to Gil, 12 March 1930, NNA 01422-01436B/57.

122 Catalan to Gil, 12 March 1930.

123 Catalan to Gil, 7 July 1931, NNA 01434/42.

124 Catalan to Raible, 5 July 1931, NNA 01434/47. 


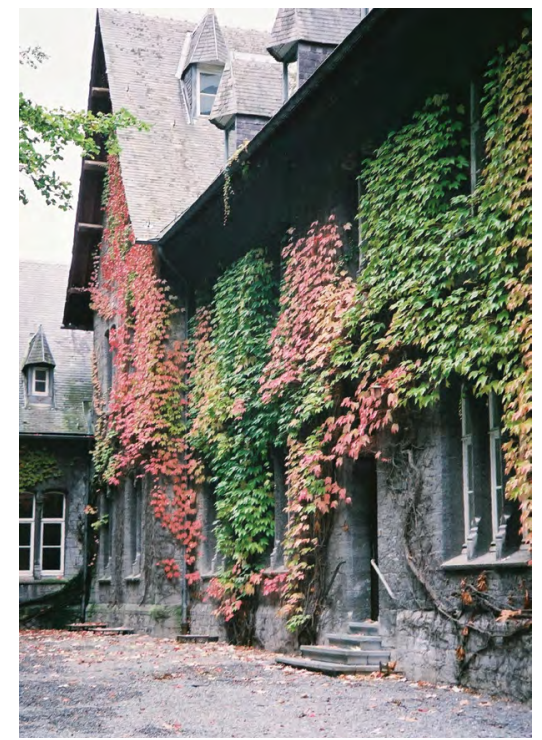

Figure 5.6: Emmaus House, Maredsous, Belgium, 2010.

Source: Author's collection.

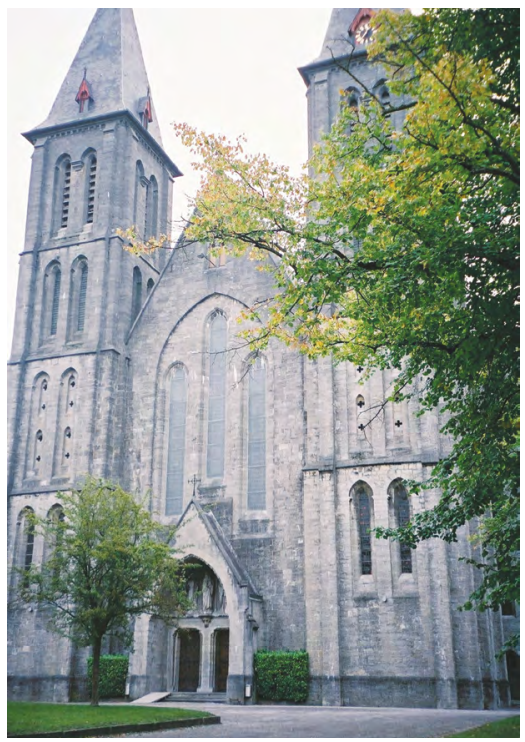

Figure 5.7: Abbey church at the monastery of Maredsous, Belgium, 2010.

Source: Author's collection.

In May and June 1931, three Benedictine sisters answered the abbot's call for volunteers to join the mission in the north. The records do not show us the process, but Abbot Catalan's letter to Fr Tomás more than hints at the practicalities. In July he could not say whether there would be two or three sisters. Gertrude, the Australian, had made a firm offer and, although not young at 52 years of age, she would be an English-speaking teacher. Some other potential volunteers were taken aback. 'That's the way things are', the abbot remarked, 'or better to say, the people. ${ }^{125}$ It is an intriguing hint at the complexity the community confronted as the women made choices that were no longer 'theoretical'. We do not know who among the Spaniards was hesitating, but a month later three sisters set out with the abbot. Escolastica Martinez was the 23-year-old superior, with Hildegard Ruiz, aged 22, as cook, and Gertrude Banks as teacher.

The journey along the coast in the Koolinda, the motorised lugger run by the state shipping service, took more than a fortnight. The passengers turned out to include a party of 30 or more tourists, as well as the children returning from Broome. Their arrival at Drysdale River on 18 August 1931

125 Catalan to Gil, 7 July 1931. 
was a 'red letter day'. ${ }^{126}$ The community of four monks 'most sincerely welcomed all, and especially the Sisters whose aid had been so earnestly solicited'. ${ }^{127}$ A group of 20 from the Aboriginal community (probably men, though the account does not say) met them with a 'typical and innocent ${ }^{128}$ dance while the tourists took photographs. The monastery's photographs stress the form of travel—boats, barges, luggers and cartsand the drama of distance and arrival again and again.

The abbot remained for four weeks, writing an account that became the basis of several articles and a radio talk. It stressed the missionary success. The new convent was blessed on 23 August 1931, after Mass sung to a setting by Dom Moreno and a procession of 120 Aboriginal people. On 7 September 1931 there was a baptism of eight Aboriginal converts and confirmation of 13 more, followed by a picnic to mark the festival. Ten days later the Koolinda returned by special arrangement, leaving six months worth of supplies and collecting the abbot. He was back at New Norcia by the end of September 1931. The arrival of the Benedictine women in the Kimberley was a major step and a sign to the Australian church and the wider community that the mission was secure into the future.

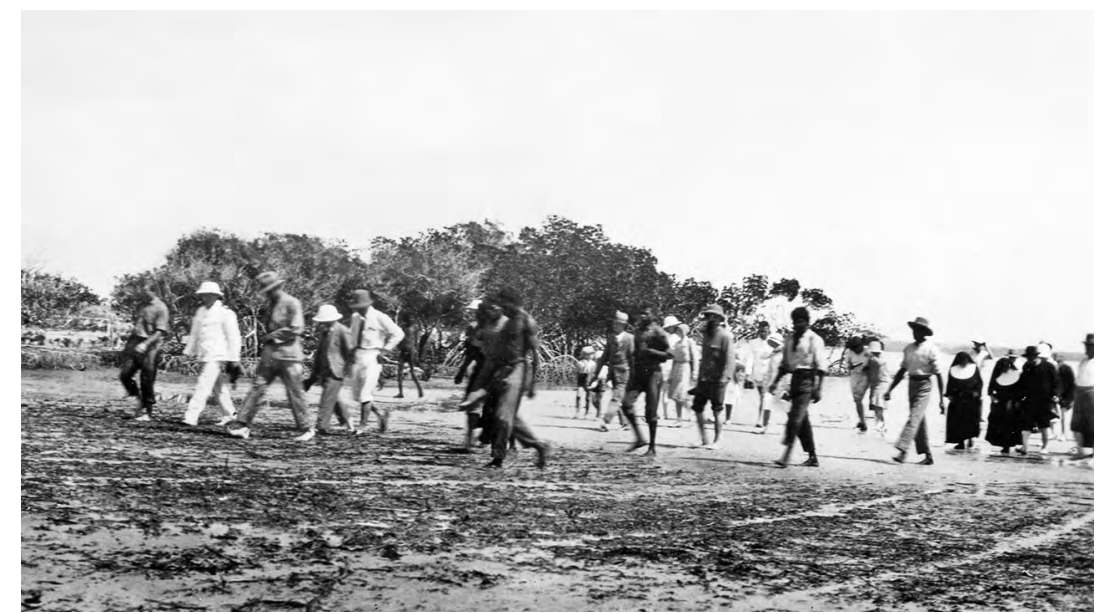

Figure 5.8: Arriving at Pago Pago Mission in the Kimberley, 18 August 1931. Benedictine sisters at right in shoes and stockings, possibly Abbot Catalan in bare feet.

Source: NNA 65179P.

126 Catalan, 'First Sisters at Drysdale River Mission', account filed with Catalan correspondence 1931, NNA 01422-01436D/133.

127 Catalan, 'First Sisters', 1931.

128 Catalan, 'First Sisters', 1931. 


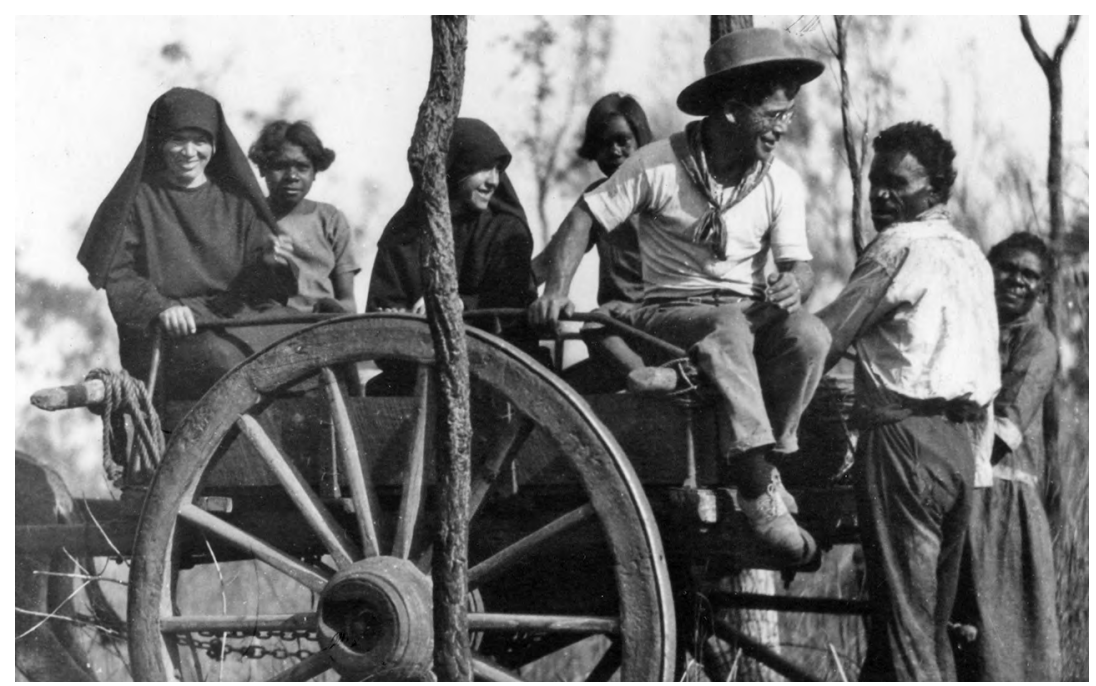

Figure 5.9: Transferring to Drysdale River site, 1932.

Source: NNA 65231P.

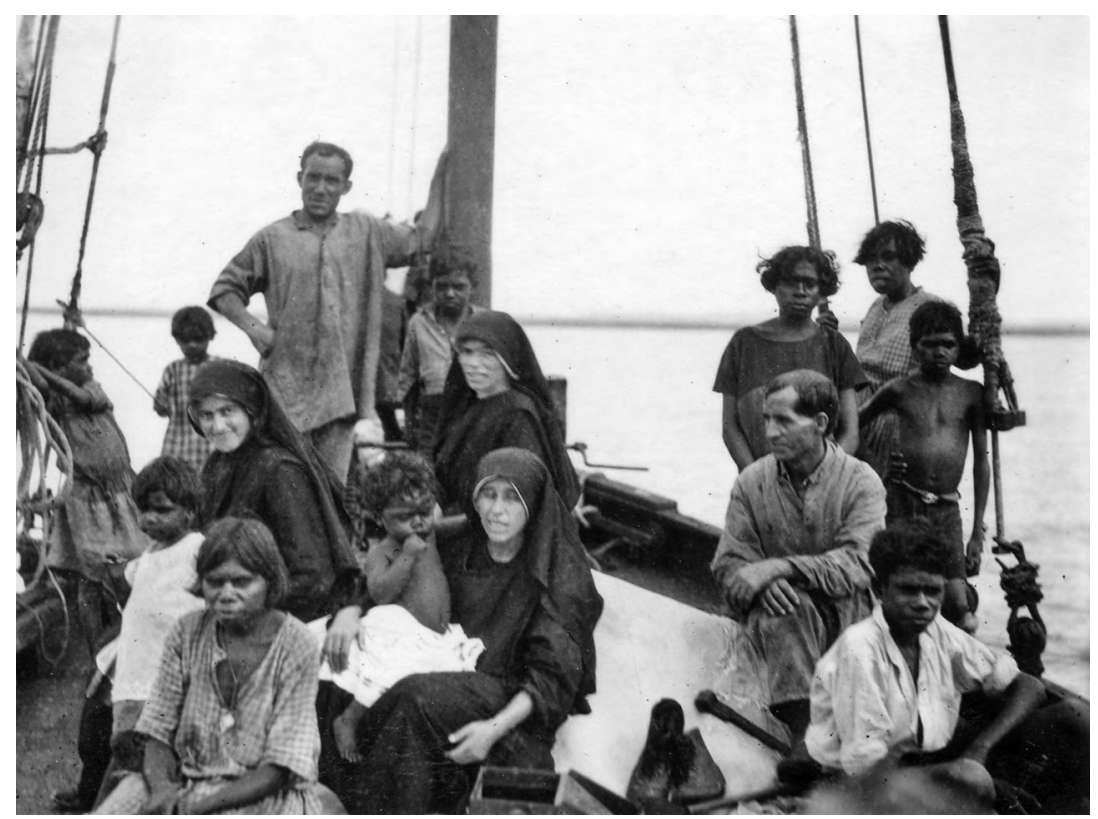

Figure 5.10: On the lugger Koolinda; Matilde, Escolastica and Hildegard with Fr Boniface and Aboriginal children.

Source: NNA 65218P. 
But if the mission in the north was going to be permanent, and if the women were to remain, surely there had to be a more secure basis for their own community. Even before he left the Kimberley the abbot could see things would not last with Sr Gertrude, ${ }^{129}$ and the durability of the new venture was tested when she took the first available boat out in January 1932. Fr Gil reported, using her English phrase, that she had told him, 'This Mission is very disappointing. ${ }^{130}$ She wrote to the abbot from Wyndham, the small port nearest Drysdale River, confessing she had fled. ${ }^{131}$ Gertrude did not explain why she had left but presented what had happened as a 'failure' of her vocation. She proposed to go to Darwin instead. ${ }^{132}$ Catalan wrote to her kindly, and directed her firmly to New Norcia. Given the canonical situation, his authority to do this was minimal, but he sent her $£ 25$ for the fare, via a letter entrusted to the captain of the Koolinda, her only means of transport. ${ }^{133}$

The abbot was concerned above all that Gertrude should not freelance as a missionary. He reassured her that the other sisters would welcome her 'with open arms'. ${ }^{134}$ Actually, he now understood that her personality was a trial to the other sisters, and he had his own reservations. He identified the cause of her distress in the north as not being able to follow her 'whim' or provide as she chose for the Aborigines. ${ }^{135}$ Abbot Catalan mused dispiritedly to Fr Tomás that some characters were able to convince everyone involved, including themselves, that they were martyrs. ${ }^{136}$ But he did not want loose talk about the mission at Drysdale reaching Darwin or Beagle Bay or circulating at New Norcia. He advised Gertrude to explain only that 'to work with success in that Mission you had to learn the native language for which you are too old'. ${ }^{137}$ Warning her against 'asking permission' for anything except a return to New Norcia, Abbot Catalan asserted the status of the group as strongly as he could. He urged Gertrude to 'straightway return to your own Home, New Norcia, and join

129 Catalan to Gertrude, 27 February 1932, NNA 01433/42; Catalan to Gil, 4 March 1932, NNA $01433 / 53$.

130 Catalan to Gil, 4 March 1932, reporting Gil's phrase back to him.

131 Gertrude Banks to Catalan, 30 January 1932, NNA 01061; Catalan to Gertrude, 27 February 1932.

132 Gertrude Banks to Catalan, January 1931, NNA 01061.

133 Catalan to Captain of the Koolinda, 10 March 1932; Catalan to Gertrude, 27 February 1932; Catalan to Gil, 4 March 1932, NNA 01433.

134 Catalan to Gertrude, 27 February 1932.

135 Catalan to Gil, 4 March 1932 (No podia disponer a su antojo, ni hacer lo que quiziera en curar a los nativos, proveerles de cosas).

136 Catalan to Gil, 4 March 1932.

137 Catalan to Gertrude, 27 February 1932. 
again to your Community and work in the Orphanage for the native girls in whatever you may be required'. ${ }^{138}$ It could only be an exhortation. As it turned out, Gertrude was grateful and complied.

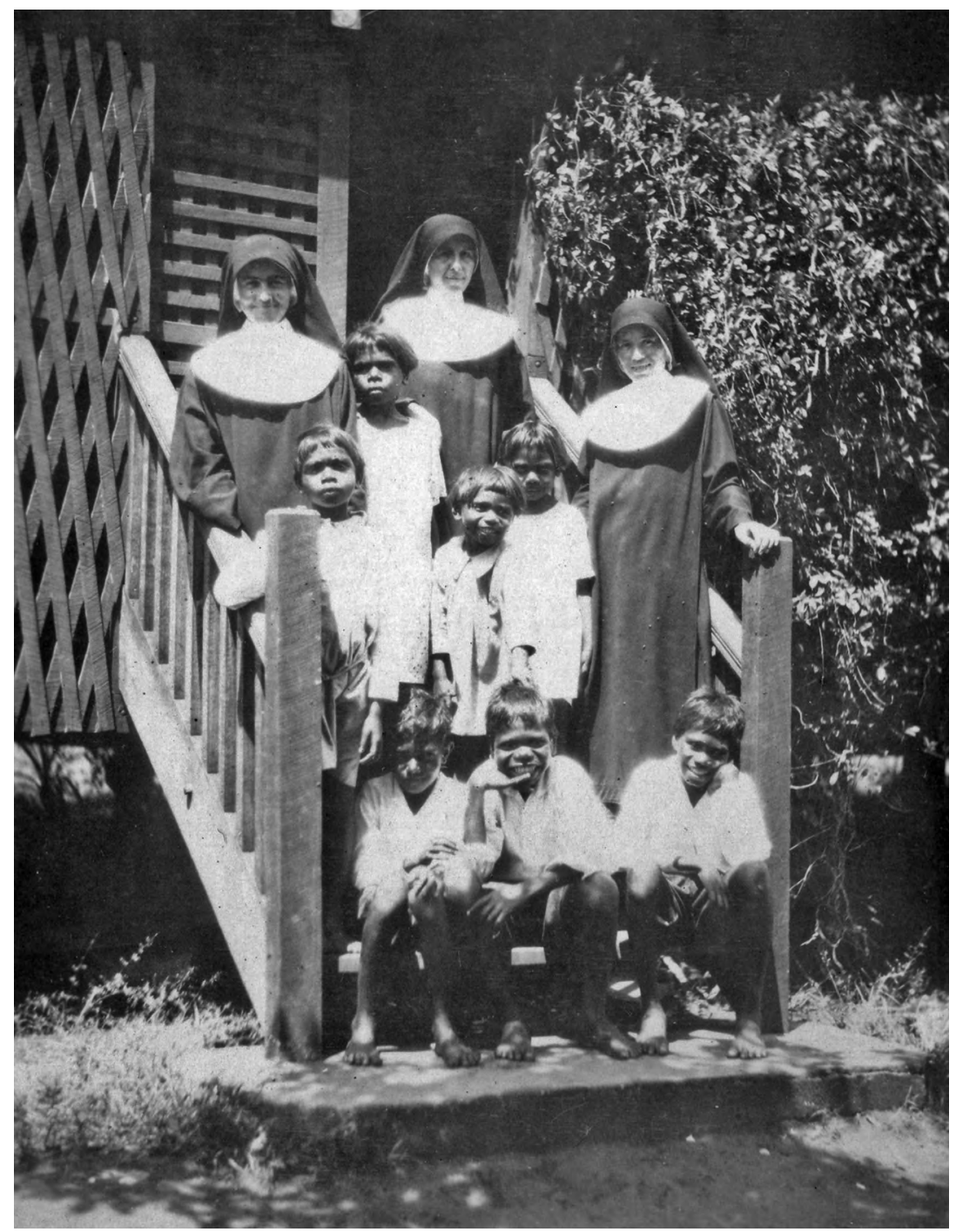

Figure 5.11: Gertrude, Escolastica and Hildegard with Aboriginal children on the steps of the first convent at Drysdale River, 1931.

Source: NNA 80487P.

138 Catalan to Gertrude, 27 February 1932. 
The need for formal structures was urgent. Fr Tomás wrote from Drysdale to clarify the 'juridical status' of the two sisters who remained. Balancing limitations with commitments, the abbot replied that they were 'only' Benedictine oblates, although their status conformed to the statutes of Leo XIII. They had taken vows 'but' privately, although Escolastica's commitment was for life, and Hildegard would make a perpetual profession 'when the time comes' ${ }^{139}$ Moving swiftly from one unwieldy topic to another, the abbot lamented the failure of a recent attempt to establish mango trees at New Norcia. It was hardly surprising that Fr Schyrgens's article on organising an oblate community should arrest the abbot's attention a few weeks later and set in train the sisters' departure for canonical training. Abbot Catalan wrote to Escolastica at Drysdale River in July 1933, promising that 'by the time this letter reaches you, Sisters Felicitas and Benita will already be in Europe ${ }^{140}$ and that the canonical community, 'which you had all so longed for', would be underway. After a long search, he had found 'Benedictine nuns who would adapt to your way of life'. ${ }^{141}$

The abbot's two-way correspondence between the Kimberley and Belgium would continue through the 1930s. The two sets of letters are compelling both for the connections between them as well as for their contrast. Felicitas and Benita wrote from the novitiate in Belgium; they were learning to make nougat and starch lace, they cooked and cleaned for the school and the monks, while struggling along in French and nourishing their missionary calling with the tradition of a European monastery. In the Kimberley, Escolastica and Hildegard were joined by Matilde in September 1932, ${ }^{142}$ returning the group to the trio of sisters first intended. They also wrote as directed in their own style without worrying about oratory. ${ }^{143}$ They sent letters down the coast whenever a mail boat called, reporting on their hopes for the local people, their work in the vegetable garden and their conversations with the women. They washed the laundry, taking it to the river, and cooked, including sweets for special occasions, while also sampling crocodile and 'the first-class meal' of dugong. ${ }^{144}$ They were anxious about the rains and the heat and assured the abbot they

139 Catalan to Gil, 5 March 1932.

140 Catalan to Escolastica, 24/26 July 1933, NNA 01434.

141 Catalan to Escolastica, 24/26 July 1933.

142 Matilde de la Fuente to Catalan, Broome, 15 September 1932, NNA 01061.

143 Catalan to Escolastica and Hildegard, 28 August 1932.

144 Escolastica to Catalan, NNA 01061, sweets: 6 July 1934, 8 February 1935; crocodile: 30 September 1934; dugong: 9 October 1936, trans. Kerry Mullan. 
were healthy. These letters might well be the only common link between Belgium and the Kimberley. But both from Europe and from the north, a shared conviction governed the sisters' writing. How simple it seemed to these women that they should be worlds away from the villages of Burgos and how much they prized their new identities as missionaries and as Benedictines. 
This text is taken from A Bridge Between: Spanish Benedictine Missionary Women in Australia, by Katharine Massam, published 2020 by ANU Press, The Australian National University, Canberra, Australia. 